\title{
AGE AND GROWTH OF THE QUEEN TRIGGERFISH Balistes vetula (TETRAODONTIFORMES, BALISTIDAE) OF THE CENTRAL COAST OF BRAZIL
}

\author{
Cristiano Queiroz de Albuquerque ${ }^{1 *}$, Agnaldo Silva Martins ${ }^{1}$, Nilamon de Oliveira Leite Junior ${ }^{2}$, \\ Julio Neves de Araújol ${ }^{l}$ and Alan Marques Ribeiro ${ }^{l}$ \\ ${ }^{1}$ Universidade Federal do Espírito Santo \\ Laboratório de Nectologia, Departamento de Oceanografia e Ecologia \\ (29075-910, Vitória, ES, Brasil) \\ ${ }^{2}$ Instituto Brasileiro do Meio Ambiente e dos Recursos Naturais Renováveis - IBAMA \\ Centro Tamar/ICMBio \\ (Av. Paulino Muller 1111, 29040-470 Vitória, ES, Brasil) \\ *Corresponding author: doccqa@yahoo.com.br
}

\section{A B S TR A C T}

Dorsal spines ( $\mathrm{n}=649)$ of the queen triggerfish Balistes vetula were collected between 1997 to 1999 at the central coast of Brazil and used to evaluate fish growth. The marginal increment analysis validated that 1 increment was formed annually $(n=476)$, with minimum values observed at the summer, and coinciding with the maximum proportion of translucent growth bands. Fish's maximum fork length and age were $460 \mathrm{~mm}$ and 14 years respectively. The parameters of the von Bertalanffy function were: $F_{l \infty}=441.3 \mathrm{~mm}, \mathrm{~K}=0.14$ and $\mathrm{T}_{0}=-1.8$. Weight gain by year ranged from about $110 \mathrm{~g}$ $\mathrm{yr}^{-1}$ for age 5 to about $30 \mathrm{~g} \mathrm{yr}^{-1}$ for age 14. Compared to other studies, B. vetula growth in the Central coast of Brazil was slow, which could be related to the influence of the oligotrophic water from Brazil current. Our results indicate that B. vetula's fisheries in the Central coast of Brazil until 1999 have caught mostly adult individuals over the sexual maturation lenght, $60 \%$ of them with ages from 6 to $8 \mathrm{yr}$.

\section{R ESUMO}

Entre 1997 e 1999 foram amostrados 649 espinhos de Balistes vetula na costa central do Brazil e foram utilizados para a avaliação de crescimento. A validação de anéis anuais de crescimento foi realizada através da analise de incrementos marginais, cujos valores mínimos foram observados durante o verão, coincidindo com a maior proporção de anéis translúcidos na borda do espinho. Portanto, forma-se um anel de crescimento a cada ano. A idade e o comprimento padrão máximos observados foram respectivamente 14 anos e $460 \mathrm{~mm}$. Os parâmetros da equação de von-Bertalanffy foram: $F_{l \infty}=441,3 \mathrm{~mm}, \mathrm{~K}=0,14 \mathrm{e} \mathrm{T}_{0}=-1,8$. O incremento anual em peso variou de $110 \mathrm{~g} \mathrm{yr}^{-1} \mathrm{para}^{\mathrm{a}}$ idade 5 a $30 \mathrm{~g} \mathrm{yr}^{-1}$ para a idade 14. Comparados a outros estudos, nossos resultados indicam taxas de crescimento mais baixas, que podem ter sido induzidas pela influência oligotrófica da corrente do Brasil ao longo da costa central do Brasil. Nossos resultados indicam que a pesca do peroá até 1999 estava principalmente voltada a indivíduos adultos, com tamanhos acima do comprimento de primeira maturação sexual e cerca de $60 \%$ dos indivíduos capturados apresentando idades entre 6 e 8 anos.

Descriptors: Balistes vetula, Marginal increment, Age determination, Reef fish, Spine Growth marks. Descritores: Balistes vetula, Incremento marginal, Anéis de crescimento em espinhos, Peixes recifais, Determinação de idades.

\section{INTRODUCTION}

The queen triggerfish Balistes vetula (LINNAEUS, 1758) is a member of the cosmopolitan marine teleost family Balistidae (order Tetraodontiformes). It is a reef fish species widely distributed throughout the Atlantic Ocean, occurring on the western margin from Canada to Uruguay, and on the eastern margin from Spain to southern Angola. Queen triggerfish are mostly found over rocky surfaces below $100 \mathrm{~m}$ deep and in shallow waters close to sandy beaches and phanerogamae prairies (MANOOCH; DRENNON, 1987). They are known to feed on a broad range of benthic prey, particularly on gastropods, echinoderms, small fish and other invertebrates (COSTA et al., 1987), using their robust jaws and strong teeth to break the hard parts of their prey (TURINGAN; WAINWRIGHT, 2005). The species is usually captured by recreational fisheries, and because of its interesting shape and bright colors, 
$B$. vetula is especially appreciated by aquariophilists, in spite of its aggressiveness. Growth and population information on $B$. vetula is quite scant. A few growth studies based on its structural hard parts were undertaken more than 20 years ago for the American Virgin Islands (MANOOCH; DRENNON, 1987) and for Brazilian central waters (MENEZES, 1985) and have indicated that this species presents longevity of more than 10 years.

In Brazil, B. vetula does not represent an important fisheries resource, being captured mostly as a by-catch of other fisheries (MARTINS; DOXSEY, 2006). Due to the good quality of its flesh, and despite sporadic incidents of human intoxication after its consumption (SZPILMAN, 1991), B. vetula has been successfully sold in markets and restaurants on the northern, northeastern and central coasts of Brazil. Recently, there has been a great decrease in the annual capture of the congeneric and more abundant species B. capriscus (MARTINS; DOXSEY, 2006) from 7,300 tons in 2002 to 770 tons in 2005. This decrease is expected to cause an increase in the exploitation of $B$. vetula by fisheries, particularly on the central coast of Brazil (MARTINS; DOXSEY, 2006; NETO, 2009). However, there are no official Brazilian catch statistics for $B$. vetula, which makes it hard to assess its real availability over time. Additionally, the queen triggerfish is believed to be at risk of extinction since it was incorporated into the IUCN Red List in 1996 with vulnerability status of A2d, which means an expected population reduction of at least $20 \%$ within the next ten years (IUCN, 2010). Moreover, it has been considered the most highly endangered coral reef fish species in Florida Key (USA) waters, due to its decline in sightings and relatively restricted occurrence range (GILLESPIE; ANAIS, 2005). In the light of this situation, it may be inferred that $B$. vetula is expected to face a further decline over the coming years.

The possible population decline of a threatened species and the paucity of biological information on the basic biology of B. vetula, necessary for management actions, motivated this study. We aim to: (1) evaluate, by the analysis of the marginal increment, whether the growth bands in the dorsal spines of $B$. vetula are deposited annually; (2) describe the growth patterns of $B$. vetula off the central coast of Brazil, and (3) estimate the von Bertalanffy growth parameters by direct age estimation using dorsal spines.

\section{Material and Methods}

Study Area

The central coast of Brazil is characterized by large variations in the width of the continental shelf, from 8 to $246 \mathrm{~km}$ (Fig. 1). The ocean bottom is mostly formed of hard substrate covered by calcareous algae and some patches of coral reefs (MELO et al., 1975). Beyond the irregular continental margin, there are two submarine ranges called Vitória-Trindade and Abrolhos (see Fig. 1). Both ranges extend up to 1100 $\mathrm{km}$ from the continental shelf and include some banks well isolated from the others. The central coast of Brazil is mainly influenced by the oligotrophic waters of the Brazil Current (NONAKA et al., 2000).

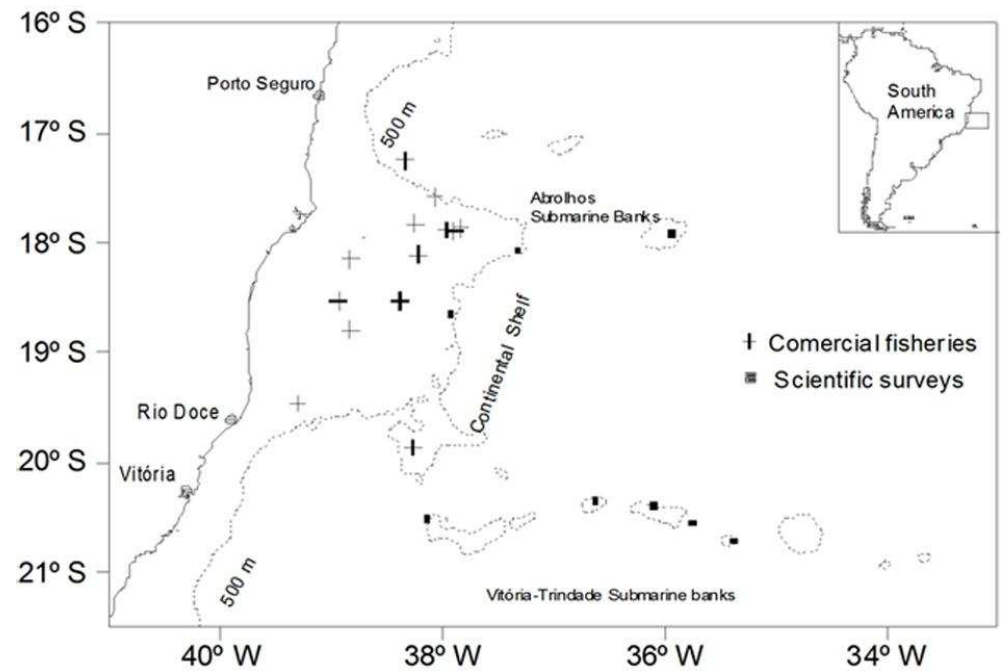

Fig. 1. Study area at Brazilian central coast, indicating sampling stations from scientific surveys (ロ) and commercial fisheries (+) where Balistes vetula were collected. 
Sampling, Spine Processing and Analysis

The fish analyzed in this study were collected between 1997 and 1999 by scientific surveys and commercial fisheries. Samples were captured using bottom longlines (scientific survey, October/November, 1997) and handlines (commercial fisheries, sampled monthly from 1998 to 1999) and totaled 649 individuals of $B$. vetula collected on the continental shelf and submarine ranges (see Fig. 1 for exact sampling locations). All specimens were measured (fork length to the nearest $1 \mathrm{~mm}$ ), weighed (in grams) and sexed (whenever possible). The first dorsal spine was fully excised from each fish, labeled and stored in plastic bags prior to further processing. Once in the laboratory, soft tissues were manually removed from the spines with a brush. Residual tissues were removed by soaking the spines in household bleach solution (50\% sodium hypochlorite) for 5 minutes, and again gently brushed under running tap water. After drying at atmospheric temperature, the spines were embedded in epoxy resin. Transverse sections $(0.5 \mathrm{~mm}$ thick) were cut close to the spine condyle with a low speed saw. Three sections from each spine were placed on glass slides over black surfaces, viewed with incident light under a stereoscope at magnification of 10 to $20 \mathrm{x}$ and then examined for evidence of age marks. Under these conditions, the translucent bands appeared as dark bands (Fig. 2). The most highly contrasting section of the growth bands was chosen for use in the growth and marginal increment analysis. The counting of the translucent bands was undertaken by two experienced readers. Average Percent Error (APE) was calculated to evaluate the precision among readings following BEAMISH AND FOURNIER (1981), in accordance with equation (1):

$$
A P E=100 \frac{1}{R} \sum_{i=j}^{R} \frac{\left|x_{i j}-x_{j}\right|}{x_{j}}
$$

where $x_{i j}$ is the $i$ th age determination of the $j$ th fish, $x_{j}$ the estimated mean age of the $j$ fish and $R$ the number of times that the age of each fish is calculated.

The periodicity of the formation of growth increments in spines was evaluated based on the Marginal Increment (MI) analysis. MI was calculated as the extra growth expressed as a proportion of the previous year's growth, in accordance with the function $(2)$.

$$
I M=\frac{\left(R_{t}-R_{t-1}\right)}{\left(R_{t-1}-R_{t-2}\right)}
$$

where $R_{t}$ is the distance measured from the core to the spine's edge, $R_{t-1}$ the distance between the core and the proximal margin of the last translucent band, and $R_{t-2}$ is the distance between the core and the proximal margin of the penultimate translucent band. All these distances were measured in micrometer scale units.

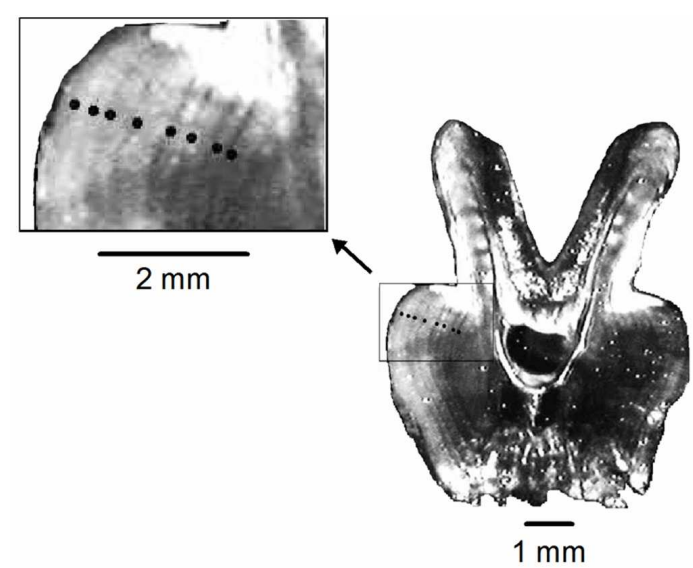

Fig. 2. Photomicrographs of a transverse section of the first dorsal spine of a 8 years old Balistes vetula. The picture was taken over black background, under incident light. Black dots indicate translucent growth bands.

According to this function, MI values close to one indicate periods when the last translucent band was almost or totally complete. This analysis was performed for individual fish grouped into 3-month periods. In order to corroborate MI interpretations, translucent and opaque bands on the spine's edge were counted for each 3-month period and displayed as relative frequencies (\%). Differences of IM among all the 3-month periods were analyzed by Analysis of Variance and the Tukey test (ZAR, 1984). Fish were assigned ages based on the number of annuli (translucent + opaque bands) on their spines.

The relationship between fish fork length and spine radius was calculated according to the linear function (3):

$$
F_{l}=a+b R_{t}
$$

where $F_{l}$ is the fork length, $a$ the intercept, $b$ the angular coefficient and $R_{t}$ the total spine radius.

Since no fish younger than 2 years were captured, the length-at-age was back-calculated in accordance with FRANCIS's (1990) equation (4):

$$
F_{l i}=\frac{\left(a+b R_{i}\right)}{(a+b R)}
$$

where $F_{l}$ is the total fork length, $F_{l i}$ the fork length corresponding to age $i, a$ and $b$ the parameters of equation (3), $R_{i}$ the spine radius at the translucent band corresponding to age $i$, and $R_{t}$ the total spine radius. 
Therefore, with the back-calculated fish lengths-at-age, we have fit the von Bertalanffy growth model (5):

$$
F_{l i}=F_{l \infty}\left\lfloor 1-e^{-k\left(t-t_{0}\right)}\right\rfloor
$$

where $F_{l i}$ is the fork length corresponding to age $i, F_{l \infty}$ the mean theoretical maximum total length, $t_{0}$ the theoretical age at zero length and $k$ a growth rate parameter. The curve parameters $\left(F_{l o \infty}, k\right.$ and $\left.t_{0}\right)$ were calculated using a non-linear iterative estimation by means of the software Statistica (STATSOFT, 1995). Differences of growth between the sexes were evaluated based on comparisons of length-at-age by sex using analysis of variance. Number of males and females by age were compared through the Chi-Square test (ZAR, 1984).

Theoretical growth in weight was estimated by transforming length-at-age in weight-at-age data based on the allometric (length-weight) equation (6).

$$
W_{t}=a F_{l}^{b}
$$

where $W_{t}$ is the fish's total weight, $a$ the condition factor, $F_{l}$ the fork length and $b$ the allometric coefficient. Absolute weight gain was calculated from the differences between the mean theoretical weight of consecutive ages (ARAÚJO; HAIMOVICI 2000).

\section{Results}

Alternating opaque and translucent growth bands were relatively clear in transverse spine sections of B. vetula from the central coast of Brazil (Fig. 2). This was established by the acceptable bias estimated between age readers (APE $=11.2 \%)$. In the majority of the spines analyzed no re-absorption of early formed annuli or lumen expansion was observed, which could lead to the underestimation of individual ages. This fact has facilitated the measurement of initial growth bands in spines of old fish. Despite the predominant absence of lumen expansion, of the 649 spines analyzed, 476 were adequate for the analysis of their growth bands. Therefore, approximately $25 \%$ of the spines analyzed were not utilizable for age evaluation. The most frequent problems occurred generally with young fish, during the processes of spine excision and section grinding, which led to mistakes in the positioning and fracturing of the sections. Sex did not apparently influence the probability of section breakability. The positions of the initial translucent bands relative to specific ages were consistent along different ages, typically with a distinct mode for each growth band (Fig. 3). The marginal increment index was significantly lower in summer than for the other seasons (Tukey, $\mathrm{P}<0.05$; Fig. $4 \mathrm{a}$ ). The proportion of opaque bands was at a minimum in summer, corroborating the marginal increment index (Fig. 4b). These results indicate that the summer was the period of translucent band formation and that only one growth increment (translucent + opaque band) is formed per year. The relationship between spine radius and fish length was linear (Fig. 5a, $\mathrm{r}=0.83$ ). The length-weight relationship displayed an allometric coefficient of 2.95 (Fig. 5b).
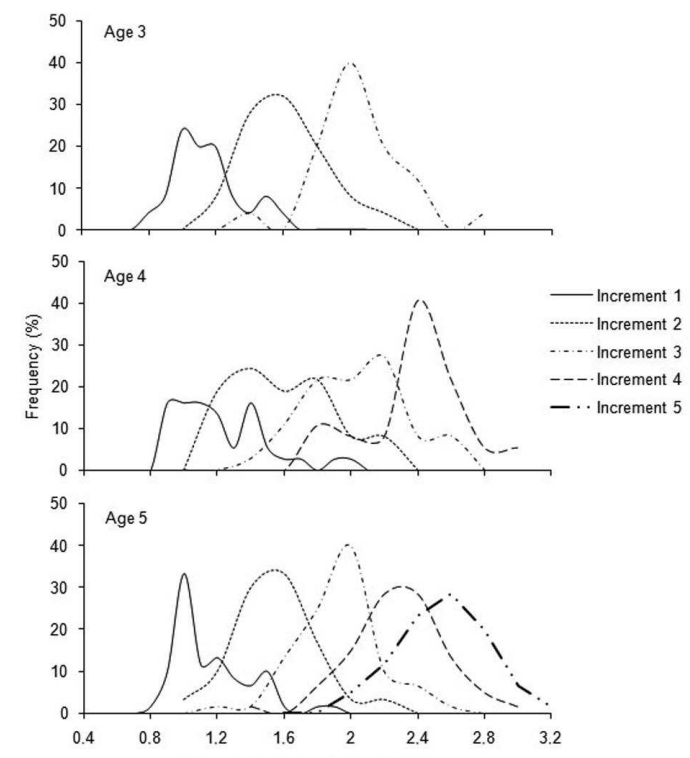

Distance from focus (Micrometric units)

Fig. 3. Spine focus-to-translucent band measurements among ages for Balistes vetula. The distances are presented in micrometer scale units and were measured using a stereomicroscope under magnification of $10 x$.
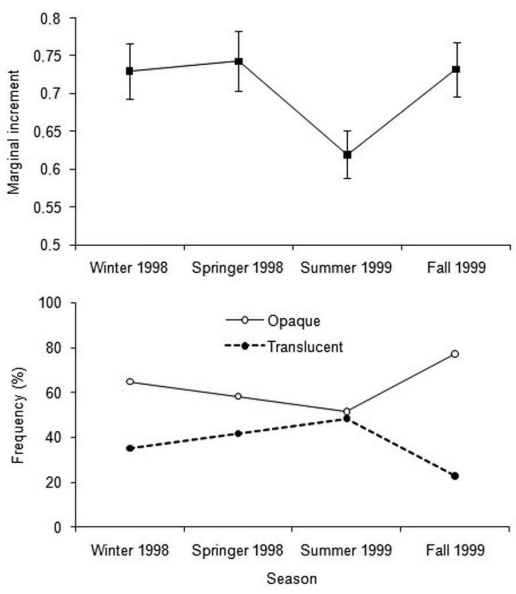

Fig. 4. Marginal increment values ( $\pm 95 \%$ confidence intervals) and proportion of opaque and translucent bands in the edge for spines of Balistes vetula from the central coast of Brazil. 

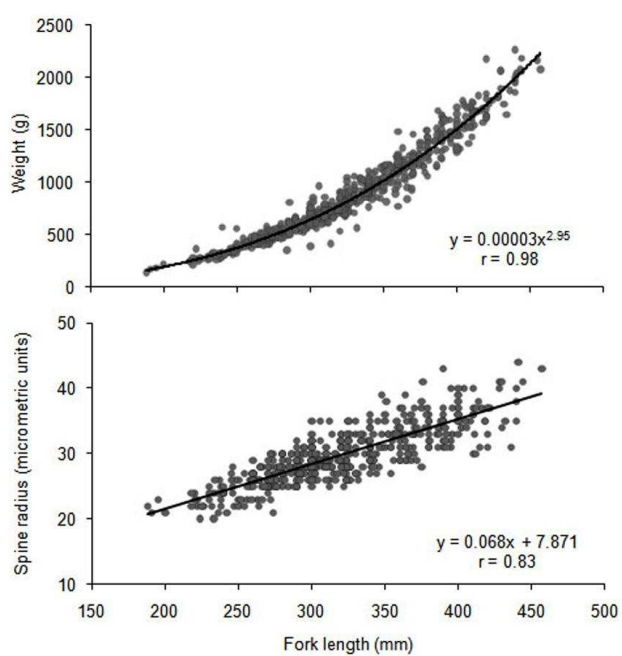

Fig. 5. Linear regression between spine radius and fork lenght for Balistes vetula from the central coast of Brazil.

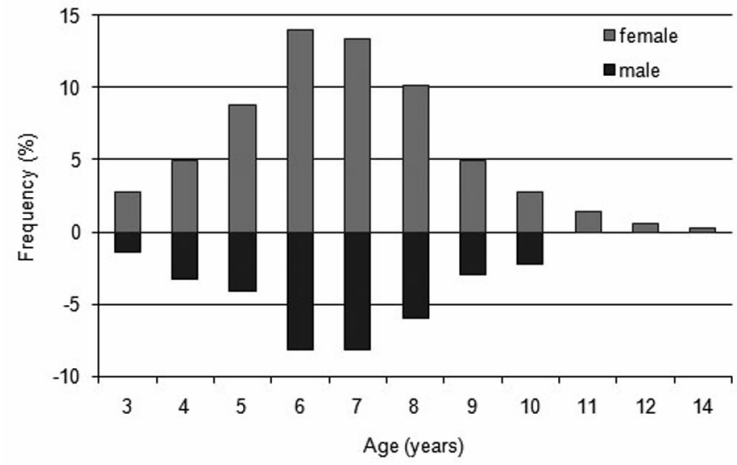

Females were significantly more abundant than males for lengths over $240 \mathrm{~mm}\left(x^{2} ; \mathrm{p}<0.05\right)$ and presented an overall proportion of 1.8:1. Fork length ranged from 180 to $460 \mathrm{~mm}$, corresponding to ages from 2 to $14 \mathrm{yr}$, with about $97 \%$ of individuals ranging from 3 to $10 \mathrm{yr}$ (Fig. 6). Mean back-calculated lengths at age are presented in Table 1. Despite the fact that only females were found to be older than $10 \mathrm{yr}$, there were no significant size-at-age differences by sex (Anova, $\mathrm{p}>0.05$ for all age classes). Therefore the data for the sexes were pooled and a single von Bertalanffy growth function was fitted for both sexes (Fig. 7a). The following parameter values were obtained: $F_{l \infty}=$ $441.3 \mathrm{~mm}, K=0.14$ and $T_{0}=-1.8$. Mean theoretical weights varied from $100 \mathrm{~g}$ at age 1 to $1200 \mathrm{~g}$ at age 14 (Fig. 7b), however, observed maximum weights have reach over $2000 \mathrm{~g}$. The mean annual growth in weight was relatively low, with absolute values ranging from about $110 \mathrm{~g} \mathrm{yr}^{-1}$ for age 5 (Fig. $7 \mathrm{~b}$ ) to about $30 \mathrm{~g} \mathrm{yr}^{-1}$ for age 14 .

Fig. 6. Age frequencies for male (black bars) and female (grey bars) Balistes vetula from central coast of Brazil.

Table 1. Description of mean back-calculated fork lengths at age $(\mathrm{mm})$, and number of analyzed spine.

\begin{tabular}{|c|c|c|c|c|c|c|c|c|c|c|c|c|c|c|c|c|}
\hline \multirow[b]{2}{*}{ Age } & \multirow[b]{2}{*}{$n$} & \multirow[b]{2}{*}{$\mathrm{F}_{\mathrm{L}}$} & \multicolumn{14}{|c|}{ Annulus } \\
\hline & & & 1 & 2 & 3 & 4 & 5 & 6 & 7 & 8 & 9 & 10 & 11 & 12 & 13 & 14 \\
\hline 2 & 1 & 262 & 173 & 223 & & & & & & & & & & & & \\
\hline 3 & 26 & 242 & 121 & 171 & 217 & & & & & & & & & & & \\
\hline 4 & 41 & 270 & 136 & 179 & 221 & 254 & & & & & & & & & & \\
\hline 5 & 62 & 300 & 141 & 184 & 220 & 254 & 282 & & & & & & & & & \\
\hline 6 & 107 & 323 & 156 & 191 & 222 & 256 & 285 & 309 & & & & & & & & \\
\hline 7 & 101 & 330 & 146 & 182 & 212 & 241 & 269 & 295 & 317 & & & & & & & \\
\hline 8 & 74 & 344 & 147 & 183 & 214 & 240 & 268 & 292 & 315 & 333 & & & & & & \\
\hline 9 & 34 & 358 & 149 & 184 & 209 & 237 & 263 & 286 & 309 & 329 & 346 & & & & & \\
\hline 10 & 20 & 368 & 147 & 187 & 213 & 240 & 267 & 287 & 309 & 331 & 348 & 365 & & & & \\
\hline 11 & 6 & 373 & 127 & 160 & 181 & 201 & 229 & 255 & 283 & 308 & 329 & 351 & 370 & & & \\
\hline 12 & 2 & 379 & 98,2 & 133 & 172 & 192 & 216 & 236 & 261 & 285 & 310 & 340 & 349 & 369 & & \\
\hline 14 & 2 & 408 & 117 & 162 & 176 & 201 & 221 & 236 & 255 & 280 & 309 & 334 & 354 & 369 & 388 & 398 \\
\hline \multicolumn{17}{|c|}{ Mean back-calculated } \\
\hline \multicolumn{3}{|c|}{$\begin{array}{l}\text { Number of spine } \\
\text { sections analyzed }\end{array}$} & 476 & 476 & 475 & 449 & 408 & 346 & 239 & 138 & 64 & 30 & 10 & 4 & 2 & 2 \\
\hline
\end{tabular}




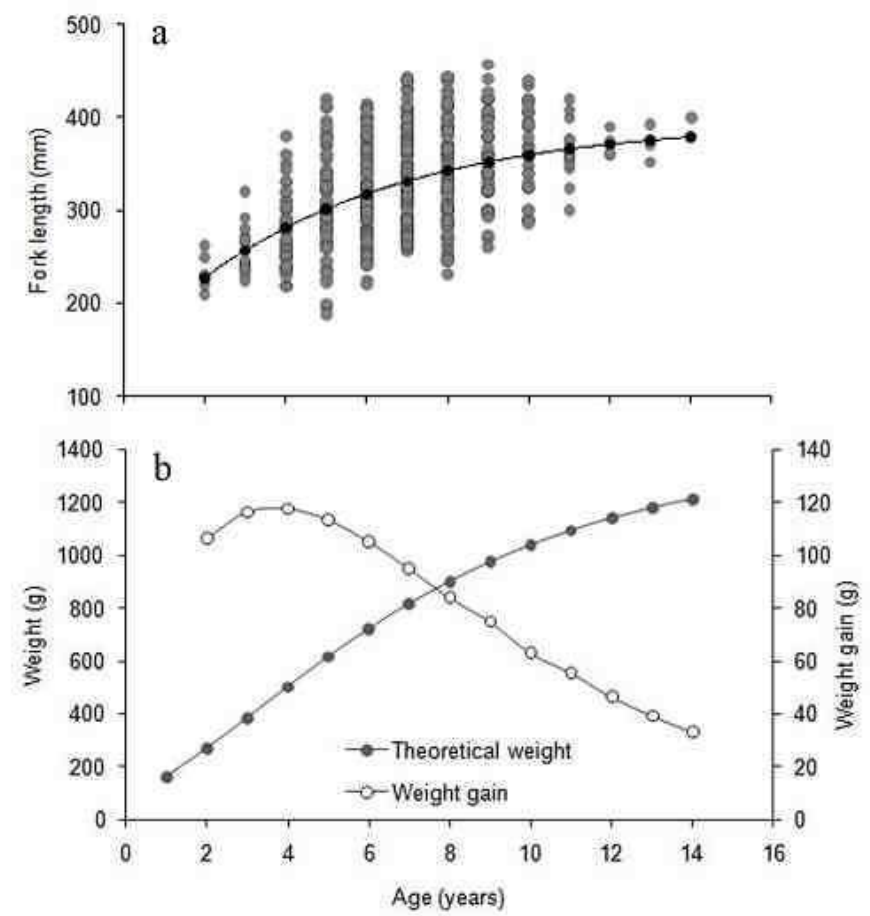

Fig. 7. Von-Bertalanffy growth curve fitted to fork length at age data (a), annual growth in weight (open circles, b), and annual weight gain (dark circles, b) by age classes for Balistes vetula.

\section{Discussion}

\section{Validation}

Spines of $B$. vetula were found to be relatively easy to examine, displaying predominantly clear translucent and opaque bands, which was confirmed by the relatively low APE values observed between readings. This attribute had been reported earlier when MANOOCH; DRENNON (1987) observed spines with large cross-sectional diameter and distinct growth rings. Surprisingly, core reabsorption or lumen expansion, features frequently found in fish spines (PRINCE et al., 1986; TSERPES; TSIMENIDES, 1995; HOOLIHAN, 2006), were almost never observed, which has increased our confidence regarding the age estimation performed here.

Opaque bands (fast growth) in spines of $B$. vetula have occurred along the year, the smallest proportion being observed in the summer, matching the minimum values registered for marginal increment. Therefore, the increment analyses support the likelihood that a single translucent band may be formed annually in spines and that this occurs during the summer. Marginal increment analysis has been considered a low performance validation method (CAMPANA, 2001), particularly for tropical fish, with regard to which the technique has been questioned because of the environmental stability typical of tropical environments (JOBLING, 2002). However, factors such as food availability, reproduction and slight variations in temperature would promote differences in fish growth, which secondarily form the growth increments in spines, otoliths and other hard structures in fish from tropical waters (FOWLER, 1990; DEVRIES; FRIE, 1996; MORALES-NIN; PANFILI, 2005; NOBREGA; LESSA, 2009). Off the central coast of Brazil, where our samples were collected, there are annual temperature variations of about $4^{\circ} \mathrm{C}$ (NIMER, 1989), which match the 4 to $5^{\circ} \mathrm{C}$ suggested as necessary to induce the production of seasonal growth increments in fish hard structures (LONGHURST; PAULY, 1987). Spines of B. vetula from the Virgin Islands have been found to form one growth band per year, mostly in winter and spring (MANOOCH; DRENNON, 1987), however the authors have not inferred which factor would be the cause of the reported annual periodicity. Studies in spines of the congenerous species B. capriscus in Southeastern Brazil have revealed the formation of two growth bands per year, which would be promoted 
by low food availability/low temperatures in winter, and reproduction in summer (BERNARDES, 2002). We have no sufficient data to objectively evaluate what is the main factor responsible for inducing the formation of growth marks in spines of B. vetula, however, the species's reproduction in Brazilian waters has been found to occur mostly in summer (MENEZES, 1979) and could be an important factor leading to decreased fish growth during this season and therefore driving the generation of annual growth increments in spines. The accuracy of our estimates was improved by analyzing the consistency of band position relative to core (Fig. 3), the edge-type proportion (Fig. 4a) and the marginal increment ratios along the year (Fig. 4b). These three analyses agreed, reinforcing the seasonal trend of growth band formation in the spines of $B$. vetula from the waters of the central Brazilian coast.

\section{Growth}

Both male and female B. vetula exhibited isometric growth, as has been previously reported for the species in Brazilian Central waters (CLARO; GARCÍA-ARTEGA, 1994; FROTA et al., 2004). However, positive and negative allometry have also been reported in other areas of occurrence, with the "b" coefficient ranging from 2.5 to 3.2 (www.fishbase.org). The length-weight relationship is expected to differ between species according to their body shapes and within a species as a function of the condition of individual fish (SCHNEIDER et al., 2000). This range may indicate that B. vetula's condition and growth patterns may be dependent on factors such as annual temperature variability or habitat differences between the areas where the individuals have been collected. In our study we took samples during an entire year and, thus, the allometry coefficient, estimated as isometric $(b=2.95)$, indicates a mean annual value for the central coast of Brazil. The growth rate of queen triggerfish was low $(0.14)$ and came close to the range observed worldwide for some of its congeneric species $(0.15$ to 0.57 ; see Table 2). The marine environments of the Brazilian central continental shelf are currently influenced by the oligotrophic waters of the Brazil current (EKAU; KNOPPERS, 1999; SILVEIRA et al., 2000), which could be one of the factors inducing the slow growth observed in our study. The worldwide-estimated range of growth rates was relatively large when compared to the small range of temperatures where those individuals were sampled $\left(24\right.$ to $28^{\circ} \mathrm{C}$; Table II). This narrow temperature range suggests that it is improbable that temperature by itself explains the observed worldwide growth differences. This variability seems more likely to be driven by differences in the methods used for growth estimation and maybe in food availability between the areas in which $B$. vetula occurs. We observed an additional variability between the lengths of individuals of similar age classes in this study. This fact is not surprising considering the large size of the sampling area and the mixed sampling approaches (commercial fisheries x scientific surveys) adopted here. On the other hand, it may also suggest that the spine may not be the best structure to evaluate age in $B$. vetula from Brazilian central waters.

The maximum age of $14 \mathrm{yr}$ exceeds those values reported for Brazilian waters in the past $(12 \mathrm{yr}$, MENEZES, 1985) and for Caribbean waters (7 yr, MANOOCH; DRENNON, 1987). The presence of individuals considerably older than the mean age sampled in our study suggests the fishery effort had not been capable of inducing changes in the age structure of the B. vetula population before 1999 .

Table 2. Growth rates and assintotic length previously reported for B. vetula and other Balistidae worldwide, according to the mean sea surface temperature where they were caught.

\begin{tabular}{lcccll}
\hline \hline Species & \multicolumn{1}{c}{$\mathrm{T}^{\mathrm{o}}$} & $\mathrm{K}$ & $\mathrm{L}_{\infty}(\mathrm{cm})$ & Latitude & Author \\
\hline Balistes vetula & $\approx 24^{\circ} \mathrm{C}$ & 0.14 & 44.1 & $18^{\circ} \mathrm{S}$ & Present study \\
Balistes vetula & $\approx 28^{\circ} \mathrm{C}$ & 0.30 & 41.5 & $18^{\circ} \mathrm{N}$ & Manooch; Drennon, 1987 \\
Balistes vetula & $\approx 27^{\circ} \mathrm{C}$ & 0.15 & 53.8 & $4^{\circ} \mathrm{S}$ & Menezes, 1985 \\
Balistes vetula & $\approx 28^{\circ} \mathrm{C}$ & 0.23 & 60.0 & $18^{\circ} \mathrm{N}$ & Randal 1962 \\
Balistes vetula & $\approx 28^{\circ} \mathrm{C}$ & 0.57 & 45.0 & $18^{\circ} \mathrm{N}$ & Aiken, 1983 \\
Balistes capriscus & $\approx 26^{\circ} \mathrm{C}$ & 0.43 & 40.8 & $5^{\circ} \mathrm{N}$ & Ofori-Danson, 1989 \\
Balistes capriscus & $\approx 26^{\circ} \mathrm{C}$ & 0.21 & 45.1 & $6^{\circ} \mathrm{N}$ & Aggrey-Fynn, 2009 \\
Balistes capriscus & $\approx 24^{\circ} \mathrm{C}$ & 0.27 & 50.9 & $23^{\circ} \mathrm{S}$ & Bernardes, 2002 \\
Balistes polylepis & $\approx 25^{\circ} \mathrm{C}$ & 0.17 & 55.8 & $23^{\circ} \mathrm{N}$ & Barroso-Soto, 2007 \\
\hline
\end{tabular}


Our data allow us to infer some interesting characteristics of the $B$. vetula fishery off the central coast of Brazil. First, MENEZES (1979) estimated first maturation at about $20 \mathrm{~cm}$ of fork length, which represents a mean age below $2 \mathrm{yr}$, according to the growth curve presented here. The larger part of the fish sampled in our study came from commercial fisheries and ranged from 6 to $8 \mathrm{yr}$ (about $60 \%$ of all the fish sampled). Consequently, the fisheries of this region exploit mostly adult fish above the length of sexual maturation. In the light of (1) the exploitation levels attained in the period before our samples were collected (1998-1999), (2) the presence of old individuals in the population, and (3) the fishing effort directed to adult fish, the queen triggerfish population on the central coast of Brazil appears not to be at risk of overfishing, collapse or extinction. However, other facts increase $B$. vetula's vulnerability to fishing. For example, the $B$. vetula fishery in Brazil is not yet regulated and the species is generally available in supermarkets throughout the year. In adittion, $B$. vetula's annual catches probably increased since 2005 due to the decrease of the congeneric species $B$. capriscus (MARTINS; DOXSEY, 2006; NETO 2009). Moreover, it is a relatively long-lived species with slow somatic growth, which means that $B$. vetula is vulnerable to intense fishing efforts (PAULY, 1980). As mentioned earlier, this species has already been included in the IUCN red list. The present changing fishing scenario could, therefore, increase the potential risk of future collapse, as well as of extinction, which justifies a call for its monitoring. Further, the absence of species-specific catch statistics makes any attempt to evaluate the stock situation using traditional tools, such as CPUE data analysis, unviable. Stocks must rather be evaluated by means of indirect evidence, such as analysis of mean size of captured specimens, growth parameters, and proportion of old individuals. Our results will, therefore, provide a reference for the monitoring and management studies which will, in the future, assess the status of the queen triggerfish population on the Brazilian central continental shelf.

\section{ACKNOWLEDGEMENTS}

The authors would like to thank all those who helped in the collection of the samples used in this study, and the anonymous referees for their helpful comments. CQA received financial support from CAPES (PNPD 02907/09-7).

\section{REFERENCES}

AGGREY-FYNN, J. Distribution and growth of gray triggerfish, Balistes capriscus (Family: Balistidae), in the Western Gulf of Guinea. West African J. appl. Ecol., v. 15 , p. 1-11, 2009.
AIKEN, K. A. The biology, ecology and bionomics of the triggerfishes, Balistidae. In: MUNRO, J. L. (Ed.). Caribbean coral reef fishery resources. Manilla: ICLARM, 1983. p. 191-205.

ARAÚJO, J. N.; HAIMOVICI, M. Determinação de idades e crescimento do linguado-branco Paralichthys patagonicus (Jordan, 1889) no Sul do Brasil. Braz. J. Oceanogr., v. 48, p. 71-79, 2000.

BARROSO-SOTO, I.; CASTILLO-GALLARDO, E.; QUIÑONEZ-VELÁSQUEZ, C.; MORÁN-ANGULO, R. E. Age and growth of the finescale triggerfish, Balistes polylepis (Teleostei: Balistidae), on the coast of Mazatlán, Sinaloa, Mexico. Pacif. Sci., v. 61, p. 121127, 2007.

BEAMISH, R. J.; FOURNIER, D. A. A method for comparing the precision of a set of age determinations. Can. J. Fish. aquat. Sci., v. 38, p. 982-983, 1981.

BERNARDES, R. A. Age, growth and longevity of the gray triggerfish, balistes capriscus (tereaodontiformes: Balistidae), from the Southeastern Brazilian Coast. Scient. Mar., v. 66, p. 167-173, 2002.

CAMPANA, S. E. Accuracy, precision and quality control in age determination, including a review of the use and abuse of age validation methods. J. Fish Biol., v. 59, p. 197-242, 2001.

CLARO, R.; GARCÍA-ARTEAGA, J. P. Crecimiento. In: CLARO, R. (Ed.). Ecología de los peces marinos de Cuba. Quintana Roo: Academia de Ciencias de Cuba y Centro de Investigaciones de Quintana Roo, 1994. p. 321-402.

COSTA, T. L. M.; VASCONCELOS-FILHO, A. L.; GALIZA-VIANA, E. M. B. Aspectos gerais sobre a alimentação do cangulo, Balistes vetula Linnaeus, 1758 (Pisces - Balistidae) no estado de Pernambuco - Brasil. Rev. Bras. Zool., v. 4, p. 71-88, 1987.

DEVRIES, D. R.; FRIES, R. V. Determination of age and growth. In: MURPHY B. R.; WILLIS, D. W. (Ed.). Fisheries techniques. Bethesda: American Fisheries Society, 1996. p 483-512.

EKAU, W.; KNOPPERS, B. An introduction to the pelagic system of the North-East and East Brazilian shelf. Arch. Fish. mar. Res., v. 47, p. 113-125, 1999.

FRANCIS, R. I. C. C. Back-calculation of fish length: a critical review. J. Fish Biol., v. 36, p. 883-992, 1990.

FROTA, L. O.; COSTA, P. A. S.; BRAGA, A. C. Lengthweight relationships of marine fishes from the central Brazilian coast. NAGA World Fish Center, v. 27, p. 2026, 2004.

FOWLER, A. J. Validation of annual growth increments in the otoliths of a small, tropical coral reef fish. Mar. Ecol. Prog. Ser., v. 64, p. 25-38, 1990.

GILLESPIE, T. W.; ANAIS, S. Conservation status of coral reef fishes in the florida keys. Endang. Spec. Update, v. 22, p. 10-24, 2005.

HOOLIHAN, J. P. Age and growth of Indo-Pacific sailfish, Istiophorus platypterus, from the Arabian Gulf. Fish. Res., v. 78, p. 218-226, 2006.

IUCN. IUCN Red List of Threatened Species. Version $2010.2<\mathrm{http}: / / \mathrm{www}$.iucnredlist.org>, accessed 10 January, 2011.

JOBLING, M. Environmental factors and rates of development and growth. In: HART, P; REYNOLDS, D. (Ed.). Handbook of fish biology and fisheries. Malden: Blackwell, 2002. p. 97-102. 
LONGHURST, A. R.; PAULY, D. Ecology of tropical oceans. London: Academic Press, 1987. 407p.

MANOOCH, C. S.; DRENNON, C. L. Age and growth of yellowtail snapper and queen triggerfish collected from the U. S. Virgin Islands and Puerto Rico. Fish. Res., v. 6, p. 53-68, 1987.

MARTINS, A. S.; DOXSEY, J. R. Diagnóstico da pesca no litoral do estado do estado do Espírito Santo. In: ISAAC, V. J.; MARTINS A. S.; HAIMOVICI, M.; ANDRIGUETTO, M. (Ed.). A pesca marinha e estuarina do Brasil no início do século XX: recursos, tecnologias, aspectos socioeconômicos e institucionais. Belém: Editora Universitária UFPA, 2006. p. 93-116.

MELO, U.; SUMMERHHAYES, C. P.; ELLIS, J. P. Upper continental margin sedimentation off Brazil. Part IV Salvador to Vitória, Southeastern Brazil. Contr. Sedimentol., v. 4, p. 78-116, 1975

MENEZES, M. F. Biologia pesqueira do cangulo, Balistes vetula Linnaeus: Reprodução e crescimento. Arq. Ciên Mar. Bras. v. 24, p. 53-59, 1985.

MENEZES, M. F. Aspectos da biologia e biometria do cangulo, Balistes vetula Linnaeus, no Nordeste do Brasil. Arq. Ciên. Mar.Bras., v. 19, p. 57-68, 1979.

MORALES-NIN, B.; PANFILI, J. Seasonality in the deep sea and tropics revisited: What can otoliths tell us? Mar Freshwat. Res., v. 56, p. 585-598, 2005.

NETO, R. F. Ecologia pesqueira do peroá (Tetraodontiformes: Balistidae: Balistes vetula) na costa leste do Brasil. 2009. 83 p. Tese (Doutorado). Universidade Estadual do Norte Fluminense Darcy Ribeiro, Rio de Janeiro, 2009.

NIMER, E. Climatologia do Brasil. Rio de Janeiro: Instituto Brasileiro de Geografia e Estatística, 1989. 421 p.

NOBREGA, M. F.; LESSA, R. P. Age and growth of the king mackerel (Scomberomorus cavalla) off the Northeastern Coast of Brazil. Braz. J. Oceanogr., v. 57, p. 273-285, 2009.

NONAKA, R. H.; MATSUURA, Y.; SUZUKI, K. Seasonal variation in larval fish assemblages in relation to oceanographic conditions in the Abrolhos Bank region off eastern Brazil. Fish. Bull., v. 98, p. 767-784, 2000.

OFORI-DANSON, P. K. Growth of grey triggerfish, Balistes capriscus, based on growth checks of the dorsal spine. Fishbyte, v. 7. p. 11-12, 1989
PAULY, D. On the interrelationships between natural mortality, growth parameters and mean environmental temperature in 175 fish stocks. J. Cons. Explor. Mer., v. 39, p. $175-192,1980$

PRINCE, E. D.; LEE, D.W.; WILSON, C. A.; DEAN, J. M., Longevity and age validation of a tag-recaptured Atlantic sailfish, Istiophorus platypterus, using dorsal spines and otoliths. Fish. Bull., v. 84, p. 493-502, 1986.

RANDALL, J. E. Tagging reef fishes in the Virgin Islands. Proc. Gulf Carib. Fish. Inst., v. 14, p. 201-241, 1983.

SILVEIRA, I. C. A.; SCHMIDT, A. C.; CAMPOS, J. D.; GODOI, S. S.; IKEDA, Y. The Brazil Current off the eastern brazilian coast. Braz J. Oceanogr., v. 48, p. 171$183,2000$.

SCHNEIDER, J. C.; LAARMAN, P. W.; GOWING, H. Length-weight relationships In: SCHNEIDER, J. C. (Ed.). Manual of fisheries survey methods. II. Ann Arbor: Michigan Department of Natural Resources, 2000. p. 1-16. (Fisheries Special Report 25).

STATSOFT. Statistica for Windows. Tulsa, Statsoft, 1995.

SZPILMAN, M. Guia prático de identificação dos peixes do litoral brasileiro. Rio de Janeiro: RBM, 1991. 286 p.

TSERPES, G.; TSIMENIDES, N. Determination of age and growth of swordfish, Xiphias gladius L., 1758, in the eastern mediterranean using anal-fin spines. Fish. Bull., v. 93, p. 594-602, 1995

TURINGAN, R.G.; WAINWRIGHT, P.C. Morphological and functional bases of durophagy in the queen triggerfish, Balistes vetula (Pisces, tetraodontiformes). J. Morphol., v. 215, p. 101-118, 2005.

ZAR, J. H. Biostatistical analysis. Englewood Cliffs, NJ: Prentice-Hall, 1984. 718 p.

(Manuscript received 26 September 2010; revised 10 March 2011; accepted 21 May 2011) 